\title{
Comparative Study of Artemether and Quinine Treatment in Severe and Complicated Falciparum Malaria at Balikpapan General Hospital
}

\author{
E. Tjitra ${ }^{*}$, S. Oemijati ${ }^{\dagger}$, T.S. Oey ${ }^{\ddagger}$, W. Pribadi ${ }^{\dagger}$, B. Tjiptaningsih ${ }^{\ddagger}$, Y. Leman ${ }^{\ddagger}$, H. Mamesah ${ }^{\ddagger}$, P.R. Arbani ${ }^{\S}$, \\ Darwoto $^{\ddagger}$, N. Syahrudji, Sudiarso ${ }^{*}$, S. Gunawan
}

\begin{abstract}
Abstrak
Untuk mendapatkan obat antimalaria alternatif yang dapat mengurangi komplikasi dan kematian, telah dilakukan uji klinis perbandingan artemeter dan kina pada penderita dewasa malaria falsiparum berat dan dengan komplikasi di RSU Balikpapan, Kalimantan Timur, Indonesia, pada tahun 1993 - 1995. Tujuan penelitian ini adalah untuk mengukur dan membandingkan efektivitas dan toleransi artemeter intramuskulus dan kina dihidroklorida intravena. Enam puluh penderita malaria falsiparum berat dan dengan komplikasi yang memenuhi syarat, diacak untuk mendapat artemeter intramuskular 1,6 $\mathrm{mg} / \mathrm{kg} \mathrm{BB/dosis,2X/haripada} \mathrm{hari} \mathrm{O} \mathrm{dan} \mathrm{dilanjutkan} 1 X /$ hari pada hari 1-4; atau kina dihidroklorida intravena $20 \mathrm{mg}$ garam $\mathrm{kg} \mathrm{BB}$ dalam $10 \mathrm{ml} / \mathrm{kg}$ BB dextrosa $5 \%$ dalam 4 jam, dilanjutkan dengan $10 \mathrm{mg}$ garam $/ \mathrm{kg} \mathrm{BB/dosis,} \mathrm{3X/hari} \mathrm{dan} \mathrm{secepatnya} \mathrm{diganti} \mathrm{dengan} \mathrm{kina} \mathrm{peroral} \mathrm{apabila} \mathrm{penderita} \mathrm{dapat} \mathrm{menelan} \mathrm{obat} \mathrm{sampai} \mathrm{total}$ mencapai 21 dosis. Mereka dirawat minimal selama 14 hari atau sampai sembuh secara klinis dan parasitologis. Dari 60 penderita tersebut ditemukan kasus 47\% dengan 1 komplikasi, 28\% dengan 2 komplikasi, 17\% dengan 3 komplikasi dan $8 \%$ dengan $>3$ komplikasi. Komplikasi yang sering ditemukan adalah hiperbilirubinemia (50\%), hiperparasitemia (28\%) dan malaria otak (25\%). Angka kematian tertinggi berhubungan dengan hiperkreatininemia, perdarahan, oedema paru, asidosis dan syok septik. Angka kematian menyeluruh adalah 18,3\% (11/60), pada kelompok artemeter 13,3\%(4/30), dan pada kelompok kina 23,3\%(7/30), tapi perbedaan ini tidak bermakna. Angka kematian karena malaria otak adalah 53,3\% (8/15). Kecenderungan kematian meningkat dengan meningkatnya jumlah komplikasi. Sampai dengan hari ke 14, tidak ditemukan perbedaan bermakna di antara ke 2 kelompok tersebut pada angka kesembuhan

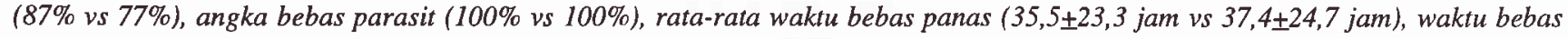
parasit $(38,9 \pm 16,9$ jam vs 41,8 14,7 jam) dan waktu kesadaran baik $(32 \pm 14,1$ jam vs $62,8 \pm 19,2$ jam). Artemeter intra muskulus adalah aman dan sama efektivitasnya dengan kina intravena pada pengobatan malaria falsiparum berat dan dengan komplikasi. Obat ini baik sebagai pengganti kina, terutama di daerah yang terpencil dimana fasilitas perawatan dan pengobatan dengan infus atau intravena tidak tersedia.
\end{abstract}

\begin{abstract}
\footnotetext{
* National Institute of Health Research and Development, Ministry of Health, Jakarta, Indonesia.

${ }^{\dagger}$ Department of Parasitology, Faculty of Medicine, University of Indonesia, Jakarta, Indonesia.

Balikpapan General Hospital, Balikpapan, East Kalimantan, Indonesia.

${ }^{\S}$ Directorate General of Communicable Disease Control and Environmental Health, Ministry of Health, Jakarta, Indonesia.
}

To obtain an alternative drug regimen to reduce the complications and mortality of malaria, a comparative clinical trial of artemether and quinine in severe and complicated falciparum malaria patients was carried out at Balikpapan General Hospital, East Kalimantan, Indonesia, in 1993-1995. The objectives of this study was to assess and compare the efficacy and safety of intramuscular artemether and intravenous quinine dihydrochloride in adult malaria patients. The sixty eligible severe and complicated falciparum malaria cases were randomized to receive either artemether intramusculary $1.6 \mathrm{mg} / \mathrm{kg} \mathrm{bw/dose} \mathrm{bid} \mathrm{on} \mathrm{day} 0$ and followed by a daily

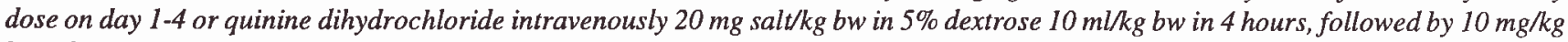
$b$ w tid which was switched to oral quinine when the patient was able to swallow oral quinine, for a total of 21 doses. They were hospitalized for at least 14 days or longer. One, two, three and more than three complications were found in $47 \%, 28 \%, 17 \%$ and $8 \%$ of the 60 patients respectively. The most common complications were hyperbilirubinaemia (50\%), hyperparasitaemia (28\%) and cerebral malaria (25\%). The highest fatality rates were associated with hypercreatininaemia, bleeding, pulmonary edema, acidosis and septic shock. The overall mortality rate was $18.3 \%(11 / 60)$. It was $13.3 \%(4 / 30)$ in the artemether group and $23.3 \%(7 / 30)$ in the quinine group, but this difference was not statistically significant. The case fatality rate of cerebral malaria cases was $53.3 \%$ (8/15). The risk of death increased with the number of complications. As assessed on day 14 , there were no significant differences between the treatment groups in the survival rate $(87 \%$ vs $77 \%)$, parasite clearance rate $(100 \%$ vs $100 \%)$, mean fever clearance time $(35.5 \pm 23.3 \mathrm{~h}$ vs $37.4 \pm 24.7 \mathrm{~h})$, mean parasite clearance time $(38.9 \pm 16.9 \mathrm{~h}$ vs $41.8 \pm 14.7 \mathrm{~h})$ and mean consciousness recovery time $(32 \pm 14.1 \mathrm{~h}$ vs $62.8 \pm 19.2 \mathrm{~h}$ ). Intramuscular artemether was well tolerated and as effective as intravenous quinine for the treatment of severe and complicated falciparum malaria. This drug is a good alternative to quinine, particularly in remote areas lacking hospitals and the capability for intravenous infusion.

Keywords : severe malaria, comparative clinical trial
This paper had been presented at the 8th National Seminar and 7th National Congress of Parasitology, Medan, 22-24 August 1996. 
The development of resistance to antimalarial drugs poses a serious therapeutic challenge especially in the treatment of severe and complicated falciparum malaria. Multidrug resistant $P$. falciparum had been reported in East Kalimantan. ${ }^{1-2}$ Therefore, new drugs with better efficacy need to be studied.

In Indonesia, severe and complicated falciparum malaria occur in about $10 \%$ of patients hospitalized with falciparum malaria. The mortality rate is up to $50 \% .^{3-7}$ Though quinine is still considered a lifesaving drug for severe malaria cases, an alternative drug to reduce the complications and mortality is desirable.

Artemisinin, a sesquiterpene lactone peroxide, was first isolated from the Chinese herb Qing-Hao (Artemesia annua $L$ ) in 1972. This drug and its derivates have powerful antimalarial activity, although their pharmacokinetic properties have not been well characterized. They have been widely and successfully used to treat severe falciparum malaria. ${ }^{8}$ Studies performed in recent years in malarious areas have confirmed the efficacy and safety of artemisinin derivates in the treatment of severe and chloroquine resistant falciparum malaria. ${ }^{9-10}$ However, it has not been established that these drugs offer advantages over quinine with regard to reducing mortality or sequelae in severe malaria.

Artemether, an oil-based methyl ether of artemisinin for intra muscular injection has a rapid schizontocidal effect in vivo. The ease of administration and the low toxicity of artemether have accounted for its replacing quinine for the first-line treatment of severe and complicated falciparum malaria in some countries. ${ }^{11-12}$ Since artemether is not yet available commercially in Indonesia, it appears worthwhile to perform an artemether clinical trial in Balikpapan, East Kalimantan to assess and compare the efficacy and safety of intramuscular artemether and intravenous quinine dihydrochloride in the treatment of severe and complicated falciparum malaria in adults.

\section{METHODS}

This study was a collaborative study between the Ministry of Health, Jakarta, the University of Indonesia, Jakarta, and Balikpapan General Hospital, Balikpapan.

Ethical clearance was obtained from The Committee of Health Research Ethics, National Institute of Health Research and Development, Ministry of Health, Jakarta, on January 14, 1993.

\section{Study site and time of study}

The study was carried out at Balikpapan General Hospital, Balik papan, East Kalimantan, Indonesia, during 1993-1995.

\section{Study design}

The study was an open label, randomized study comparing intramuscular artemether with intravenous quinine dihydrochloride for the treatment of severe and complicated falciparum malaria in adult patients.

\section{Drugs}

Artemether was supplied by Rhone Poulenc Rorer Doma, and packaged in $1 \mathrm{ml}$ ampoule of $80 \mathrm{mg}$ artemether. Quinine dihydrochloride was purchased from Kimia Farma and packaged in $2 \mathrm{ml}$ ampoule of $250 \mathrm{mg}$ base of quinine dihydrochloride $/ \mathrm{ml}$. Primaquine $15 \mathrm{mg}$ base/ tablet and tetracycline $250 \mathrm{mg} / \mathrm{cap}-$ sule were also purchased from Kimia Farma.

\section{Patients}

Sixty severe and complicated falciparum malaria patients were selected according the WHO criteria for in vivo antimalarial sensitivity testing. ${ }^{13}$ These criteria were:

1. Over 12 years of age.

2. Female should be non-pregnant or non-lactating.

3. The presence of asexual forms of P. falciparum in blood smears.

4. No ingestion of antimalarial drug in the previous 12 hours.

5. No history of hypersensitivity to antimalarials.

6. The absence of any other serious illness.

7. Informed consents were obtained from the patients or their relatives.

The presence of one or more of the following manifestations in falciparum malaria patients was sufficient for the diagnosis of severe and complicated falciparum malaria: ${ }^{14-17}$

\section{Cerebral malaria}

Glasgow Coma Scale (GCS) was used to assess the depth of coma in cerebral malaria. A total score of GCS less than 9 and persisting for more than 30 minutes after convulsion was considered unrousable coma.

\section{Impaired consciousness}

The unconscious malaria patient was still rousable, responded to stimulus and could be awakened. 


\section{Repeated generalized convulsions}

Malaria with more than two generalized convulsions within 24 hours despite fever control.

\section{Prostration, extreme weakness}

The malaria patient could not sit or walk with unexplainable neuropathology.

Fluid, electrolyte and acid-base disturbances

Malaria with dehydration and or acidosis with arterial blood $\mathrm{PH}<7.25$ and plasma bicarbonate $<15 \mathrm{mmol} / \mathrm{l}$.

\section{Circulatory collapse (algid malaria)}

Malaria with hypotension (systolic BP less than $70 \mathrm{~mm}$ $\mathrm{Hg}$ in supine position) and signs of peripheral circulatory failure such as cold, clammy, cyanotic skin and constriction of peripheral vessels.

Spontaneous bleeding and clotting disorders or disseminated intravascular coagulation (DIC)

Malaria with retinal or subconjunctival haemorrhages, bleeding from the gums, epistaxis, melena, haematemesis and/or signs of DIC such as increased plasma fibrinogen and decreased antithrombin III.

\section{Pulmonary edema}

Malaria with cough, a feeling of oppression in the chest and difficulty in breathing, dyspnea, crepitations and cyanosis.

\section{Gastrointestinal symptoms}

Malaria with persistent vomiting and/or diarrhoea.

\section{Hyperpyrexia}

Malaria with body temperature (axillary) above $40.5^{\circ} \mathrm{C}$ or $105^{\circ} \mathrm{F}$.

\section{Severe anaemia}

Malaria with a normocytic anaemia, haematocrit less than $15 \%$ or haemoglobin less than $5 \mathrm{~g} \%$.

\section{Jaundice}

Malaria with jaundice, palpable liver and bilirubin more than $50 \mu \mathrm{mol} / 1$ or more than $3 \mathrm{mg} \%$.

\section{Hypoglycaemia}

Malaria with blood sugar less than $40 \mathrm{mg} \%$ or less than $2.2 \mathrm{mmol} / 1$, symptoms of anxiety, confusion, breathlessness, sweating and neurological symptoms.

\section{Renal failure}

Malaria with urine output less than $400 \mathrm{ml}$ in 24 hours after rehydration and a serum creatinine more than 265 $\mu \mathrm{mol} / \mathrm{l}$ or more than $3 \mathrm{mg} \%$.

\section{Haemoglobinuria and blackwater fever}

Malaria with black urine rather than red or brown as in other cases of massive haemolysis.

\section{Hyperparasitaemia}

Malaria with the density of asexual forms of $P$. falciparum in the peripheral blood smears exceeding $5 \%$ of the erythrocytes (more than 250,000 parasite per $\mu 1$ at normal red cell counts).

\section{Setting}

All patients were hospitalized and observed clinically and parasitologically for at least $\mathbf{1 4}$ days or untill the patient was cured.

\section{Clinical evaluation}

A thorough history was taken and physical examination was performed on each study subjects at the time of admission. Physical examination was repeated daily during hospitalization. Daily axillary temperatures were taken 4 hourly at $2^{\circ 0}, 6^{\circ 0}, 10^{\circ 0}$ a.m. and p.m. until the patient became afebrile $\left(<37.5^{\circ} \mathrm{C}\right)$ for 24 hours. Thereafter, temperatures were taken daily.

Thick and thin blood smears were taken 12 hourly at $8^{\circ 0}$ a.m. and p.m. for parasite counts until the asexual forms were cleared for 3 consecutive examinations. Thereafter, smears were performed daily until discharge.

Routine haematology (haematocrit, haemoglobin, red cell count, white cell count, platelet count and reticulocyte count) and biochemistry (SGOT, SGPT, alkaline phosphatase, bilirubin, protein, BUN, creatinine and glucose) were done on admission (pretreatment), on discharge (post-treatment), and at other times depending on the clinical state of the patient. Other investigations were done if clinically indicated e.g.: lumbar puncture, EKG, chest X-ray and electrolyte analysis.

Patients were reviewed at least once a day.

\section{Treatment}

Thirty patients were treated with intramuscular artemether $1.6 \mathrm{mg} / \mathrm{kg}$ bw, 12 hourly on day 0 and daily on day 1-4. Another 30 patients were treated with 
intravenous quinine dihydrochloride $20 \mathrm{mg}$ salt $/ \mathrm{kg}$ bw or $16.7 \mathrm{mg}$ base $/ \mathrm{kg}$ bw in $10 \mathrm{ml} / \mathrm{kg}$ bw of $5 \%$ dextrose infused in 4 hours followed by $10 \mathrm{mg}$ salt or $8.3 \mathrm{mg}$ base $/ \mathrm{kg}$ bw, 8 hourly. As soon as the patient could swallow medication, intravenous quinine was replaced by oral quinine sulphate $10 \mathrm{mg}$ salt $/ \mathrm{kg}$ bw/dose, 8 hourly, up to a total of 21 doses.

In addition, all patients were also treated with primaquine $30 \mathrm{mg}$, single dose, to get radical cured. It was given when the patients could swallow the drug or on the last day of treatment.

Patients who had persistent positive blood smears or negative smears followed by positive smears on day 7 , or day 14 , were treated with quinine sulphate orally 10 $\mathrm{mg} \mathrm{salt} / \mathrm{kg}$ bw, 8 hourly for 7 days and tetracycline 500 $\mathrm{mg}, 8$ hourly for 7 days. All patients were followed up for 14 days after treatment.

\section{Data analysis}

The efficacy or therapeutic response of these antimalarial drugs was measured by survival rate (SR), parasite clearance rate (PCR), fever clearance time (FCT), parasite clearance time (PCT) and recovery time (RT).

SR was defined by the survival at the end of the hospitalization period (14 days). PCR was the proportion of cases showing clearance of asexual forms of parasites by day 14 .

The rapidity of the response was based on FCT, PCT and RT. FCT was the time (hours) after treatment required for body temperature to return to normal (< $37.5^{\circ} \mathrm{C}$ ). PCT was the time (hours) after treatment required for parasite count to fall below the level of microscopic detection. RT was the time taken for the cerebral malaria patients to completely recover from unconsciousness.

A side effect was defined as a symptom or sign appearing only after drug administration, that was not the classic symptom or sign of malaria infection.

\section{Statistical analysis}

Chi-square $\left(\mathrm{X}^{2}\right)$ and Fisher's exact tests were used to compare the characteristics, clinical presentations, survival rate, parasite clearance rate and case fatality rate in the artemether and quinine groups. Unpaired Student's t-test was used to compare the characteristics, haematology and biochemistry values, fever and parasite clearance times and consciousness recovery time between the two groups.

\section{RESULTS}

Of the 60 severe and complicated falciparum malaria patients, there were $51(85 \%)$ males and $9(15 \%)$ females, ranging in age and weight between 15 and 64 years, and 40 and $71 \mathrm{~kg}$ respectively. Among them, only $8(13 \%)$ were native and only $3(5 \%)$ had previously experienced malaria in the last 6 months with frequency ranging between 1 and 3 times. Duration of illness, axillary temperatures and parasite counts on admission ranged between 3 and 16 days, 36 and $40.8^{\circ} \mathrm{C}$, and 174 and $384,780 / \mu 1$ respectively.

\section{Comparative characteristics between treatment groups}

Comparison of the characteristics (age, sex, race, duration of illness, previous history of malaria, malaria frequency in the last 6 months, weight, axillary temperature and parasite count) revealed no significant differences between the two groups (Table 1).

\section{Comparative clinical presentations between treat- ment groups at enrollment}

The most frequent ( $>50 \%$ ) clinical symptoms and signs in both groups were fever, hepatomegaly, jaundice, pallor and splenomegaly. Oliguria or anuria and cough were more common in the artemether group, abdominal pain in the quinine group, and these differences were statistically significant (Table 2 ).

\section{Comparative laboratory test results between treatment groups}

Most results of routine haematology and biochemistry examinations were abnormal on admission (pre-treatment), except the white cell and platelet counts, serum protein and glucose which were within normal values. There were no differences between the two groups except for a lower platelet count in the quinine group (Table 3).

The results of all laboratory tests from both groups improved and became normal on discharge from the hospital (post-treatment). There were no significant differences between the two groups (Table 4).

\section{Clinical manifestations and morbidity rates in the treatment groups}

Among 60 severe and complicated falciparum malaria patients, $28(47 \%), 17(28 \%), 10(17 \%)$ and $5(8 \%)$ were cases with single, two, three and more than three 
Table 1. Comparison of characteristics of severe and complicated falciparum malaria patients between the treatment groups on admission at Balikpapan General Hospital, Balikpapan, East Kalimantan, 1993-1995.

\begin{tabular}{|c|c|c|c|}
\hline Characteristic & $\begin{array}{l}\text { Artemether } \\
\text { group }\end{array}$ & $\begin{array}{c}\text { Quinine } \\
\text { group }^{\dagger}\end{array}$ & $\begin{array}{l}\text { Student's t or } \\
\text { chi-square test }\end{array}$ \\
\hline Age $=(\bar{x} \pm S D)$ year & $28 \pm 10$ & $28 \pm 10$ & NS \\
\hline Sex $=$ male $:$ female & $26: 4$ & $25: 5$ & NS \\
\hline Race $=$ native $:$ others & $4: 26$ & $4: 26$ & NS \\
\hline Duration of illness $=(\bar{x} \pm S D)$ day & $8 \pm 5$ & $9 \pm 4$ & NS \\
\hline Malaria previously $=$ yes $:$ no & $1: 29$ & $2: 28$ & NS \\
\hline $\begin{array}{l}\text { Malaria frequency in the last } 6 \mathrm{mo}= \\
(\overline{\mathrm{x}} \pm \mathrm{SD}) \text { time }\end{array}$ & $1 \pm 0$ & $2 \pm 1$ & NS \\
\hline Weight $=(\overline{\mathrm{x}} \pm S D) \mathrm{kg}$ & $51 \pm 4$ & $52 \pm 6$ & NS \\
\hline Axillary temperature $=(\overline{\mathrm{x}} \pm \mathrm{SD})^{\circ} \mathrm{C}$ & $38.6 \pm 1.3$ & $38.8 \pm 1.5$ & NS \\
\hline Parasite count $=(\overline{\mathrm{x}} \pm \mathrm{SD}) / \mu \mathrm{l}$ & $57,673 \pm 62,551$ & $80,335 \pm 100,465$ & NS \\
\hline
\end{tabular}

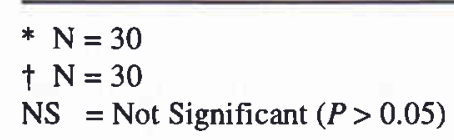

Table 2. Comparison of clinical presentations of severe and complicated falciparum malaria patients between the treatment groups on admission at Balikpapan General Hospital, Balikpapan, East Kalimantan, 1993-1995.

\begin{tabular}{lccc}
\hline Clinical events & $\begin{array}{c}\text { Artemether } \\
\text { group (\%) }\end{array}$ & $\begin{array}{c}\text { Quinine } \\
\text { group (\%) }\end{array}$ & $\begin{array}{c}\text { Chi-square } \\
\text { test }\end{array}$ \\
\hline Fever & $23(77)$ & $28(93)$ & NS \\
Hepatomegaly & $22(73)$ & $19(63)$ & NS \\
Jaundice & $20(67)$ & $24(80)$ & NS \\
Pallor & $18(60)$ & $15(50)$ & NS \\
Splenomegaly & $18(60)$ & $15(50)$ & NS \\
Headache & $16(53)$ & $13(43)$ & NS \\
Nausea & $13(43)$ & $17(57)$ & NS \\
Impaired consciousness & $9(30)$ & $11(37)$ & NS \\
Chill & $9(30)$ & $16(53)$ & NS \\
Vomiting & $7(23)$ & $14(47)$ & NS \\
Brownish/blackish urine & $7(23)$ & $10(33)$ & NS \\
Oliguria/anuria & $6(20)$ & $1(3)$ & S \\
Cough & $5(17)$ & $1(3)$ & S \\
Abdominal pain & $4(13)$ & $10(33)$ & S \\
Ronchi/crepitation & $2(7)$ & $2(7)$ & NS \\
Convulsion & $1(3)$ & $1(3)$ & NS \\
Diarrhoea & $1(3)$ & 0 & \\
Bleeding & 0 & $2(7)$ & \\
Dyspnoea & 0 & $1(3)$ & \\
\hline & & & \\
\hline S & & & \\
\hline
\end{tabular}

$* \mathrm{~N}=30$

$\dagger \mathrm{N}=30$

NS $=$ Not Significant $(P>0.05)$

$S \quad=$ Significant $(P<0.05)$ 
Table 3. Comparison of laboratory tests of severe and complicated falciparum malaria patients between the treatment groups on admission (pre-treatment) at Balikpapan General Hospital, Balikpapan, East Kalimantan, 1993-1995.

\begin{tabular}{lccc}
\hline Laboratory test & $\begin{array}{c}\text { Artemether } \\
\text { group } \\
(\bar{x} \pm \mathrm{SD})\end{array}$ & $\begin{array}{c}\text { Quinine } \\
\text { group } \\
(\overline{\mathrm{x}} \pm \mathrm{SD})\end{array}$ & $\begin{array}{c}\text { Student's } \\
\text { t-test }\end{array}$ \\
\hline Haematocrit (\%) & $30 \pm 8$ & $28 \pm 11$ & NS \\
Haemoglobin (g\%) & $9.2 \pm 3.2$ & $9.1 \pm 3.6$ & NS \\
Red cell count (/pl) & $3.2 \pm 0.9$ & $3.1 \pm 1.1$ & NS \\
White cell count (/nl) & $8.4 \pm 5.5$ & $7.4 \pm 4.2$ & NS \\
Platelet (/nl) & $219.4 \pm 68.6$ & $188.0 \pm 32.2$ & S \\
Reticulocyte (\%) & $4.6 \pm 3.1$ & $4.1 \pm 3.0$ & NS \\
SGOT/ASAT (IU) & $52 \pm 38$ & $44 \pm 32$ & NS \\
SGPT/ALAT (IU) & $48 \pm 40$ & $41 \pm 25$ & NS \\
Alkaline phosphatase (IU) & $229 \pm 311$ & $187 \pm 73$ & NS \\
Total bilirubin (mg\%) & $5.1 \pm 6.6$ & $4.7 \pm 4.5$ & NS \\
Protein (mg\%) & $6.2 \pm 1.1$ & $6.3 \pm 0.2$ & NS \\
BUN (mg\%) & $78 \pm 105$ & $67 \pm 62$ & NS \\
Creatinine (mg\%) & $1.9 \pm 2.1$ & $1.5 \pm 1.3$ & NS \\
Glucose (mg\%) & $119 \pm 42$ & $112 \pm 41$ & \\
\hline
\end{tabular}

$* \mathrm{~N}=30$

$\dagger \mathrm{N}=30$

NS $=$ Not Significant $(P>0.05)$

$\mathrm{S}=$ Significant $(P<0.05)$

Table 4. Comparison of laboratory tests of severe and complicated falciparum malaria patients between the treatment groups on discharge (post-treatment) at Balikpapan General Hospital, Balikpapan, East Kalimantan, 1993-1995.

\begin{tabular}{lccc}
\hline Laboratory test & $\begin{array}{c}\text { Artemether } \\
\text { group }^{*}\end{array}$ & $\begin{array}{c}\text { Quinine } \\
(\mathrm{x} \pm \mathrm{SD})\end{array}$ & $\begin{array}{c}\text { Student's } \\
(\mathrm{x} \pm \mathrm{SD})\end{array}$ \\
\hline t-test
\end{tabular}

$* \mathrm{~N}=26$

$+\mathrm{N}=23$

NS $=$ Not Significant $(P>0.05)$ 
complications respectively. The common clinical complications found in malaria were hyperbilirubinaemia, severe anaemia, and hyperbilirubinaemia and hyperparasitaemia in the artemether group; hyperpyrexia, hyperbilirubinaemia, severe anaemia, and cerebral malaria in the quinine group. The risk of death increased with the number of complications (Table 5).

The most common complications of severe and complicated falciparum malaria patients were hyperbilirubinaemia $(50 \%)$, hyperparasitaemia $(28 \%)$ and cerebral malaria (25\%). However, the highest fatality rates were associated with hypercreatininaemia $(100 \%)$, bleeding $(100 \%)$, pulmonary edema $(100 \%)$, acidosis $(100 \%)$ and septic shock (100\%). No fatal cases were found in patients with hyperpyrexia, and nausea and vomiting (Table 6).

The overall mortality rate of severe and complicated falciparum malaria patients was $18.3 \%(11 / 60)$, and in the artemether and quinine group were $13.3 \%(4 / 30)$ and $23.3 \%(7 / 30)$ respectively. This difference was not statistically significant (Table 5). The case fatality rates were also not significantly different when analysed in subgroups (hyperbilirubinaemia, hyperparasitaemia, cerebral malaria, severe anaemia and impaired consciousness). Most of the patients ( 3 out of 4 patients, range 1-3 days) died before day 3 in the artemether group and only a few ( 2 out of 7 patients, range 0-8 days)) died in the quinine group (Table 6).

Table 5. Number of complication and outcomes of the treatment groups of severe and complicated falciparum malaria patients at Balikpapan General Hospital, East Kalimantan, 1993-1995.

\begin{tabular}{ccccccc}
\hline Number of complication & \multicolumn{2}{c}{ Artemether group } & \multicolumn{2}{c}{ Quinine group } & \multicolumn{2}{c}{ Total } \\
& $\mathrm{N}$ & died (\%) & $\mathrm{N}$ & died (\%) & $\mathrm{N}$ & died (\%) \\
\hline 1 & 13 & \multicolumn{1}{l}{0} & 15 & $1(6.7)$ & 28 & $1(3.6)$ \\
2 & 12 & $2(16.7)$ & 5 & $2(40.0)$ & 17 & $4(23.5)$ \\
3 & 3 & 0 & 7 & $3(42.9)$ & 10 & $3(30.0)$ \\
$>3$ & 2 & $2(100)$ & 3 & $1(33.3)$ & 5 & $3(60.0)$ \\
\hline Total & 30 & $4(13.3)^{*}$ & 30 & $7(23.3)^{*}$ & 60 & $11(18.3)$ \\
\hline
\end{tabular}

* $\quad=$ No Significant Difference $(P>0.05)$

$\mathrm{N} \quad$ = Number of patients

Died $=$ Number of patients died

Table 6. Complications and outcomes of the treatment groups of severe and complicated falciparum malaria patients at Balikpapan General Hospital, Balikpapan, East Kalimantan, 1993-1995.

\begin{tabular}{|c|c|c|c|c|c|c|c|}
\hline \multirow[t]{2}{*}{ Complication } & \multicolumn{2}{|c|}{ Artemether group } & \multicolumn{2}{|c|}{ Quinine group } & \multicolumn{2}{|c|}{ Total } & \multirow{2}{*}{$\begin{array}{c}\text { Chi-square } \\
\text { test }\end{array}$} \\
\hline & $\mathrm{N}$ & $\operatorname{died}(\%)$ & $\mathrm{N}$ & $\operatorname{died}(\%)$ & $\mathbf{N}$ & $\operatorname{died}(\%)$ & \\
\hline Hyperbilirubinaemia & 16 & $4(25)$ & 14 & $2(14.3)$ & 30 & $6(20)$ & NS \\
\hline Hyperparasitaemia & 9 & $1(11.1)$ & 8 & $3(37.5)$ & 17 & $4(23.5)$ & NS \\
\hline Cerebral malaria & 8 & $3(37.5)$ & 7 & $5(71.4)$ & 15 & $8(53.3)$ & NS \\
\hline Severe anaemia & 6 & 0 & 5 & $1(20,0)$ & 11 & $1(9.1)$ & NS \\
\hline Hyperpyrexia & 4 & 0 & 7 & 0 & 11 & 0 & \\
\hline Nausea and vomiting & 3 & 0 & 3 & 0 & 6 & 0 & \\
\hline Hypercreatininaemia & 3 & $3(100)$ & 2 & $2(100)$ & 5 & $5(100)$ & \\
\hline Impaired consciousness & 1 & 0 & 4 & $1(25)$ & 5 & $1(20)$ & NS \\
\hline Bleeding & 1 & $1(100)$ & 1 & $1(100)$ & 2 & $2(100)$ & \\
\hline Pulmonary edema & 1 & $1(100)$ & 1 & $1(100)$ & 2 & $2(100)$ & \\
\hline Acidosis & 0 & 0 & 2 & $2(100)$ & 2 & $2(100)$ & \\
\hline Septic shock & 0 & 0 & 1 & $1(100)$ & 1 & $1(100)$ & \\
\hline
\end{tabular}

NS $=$ Not Significant $(P>0.05)$

$\mathrm{N}=$ Number of patients

Died $=$ Number of patients died 


\section{Comparative efficacy between treatment groups}

Of the 60 severe and complicated falciparum malaria patients, $26(87 \%)$ cases in the artemether group and $23(77 \%)$ cases in the quinine group were still alive on day 14 . By day 14 , the parasite clearance rates were $100 \%$ in both groups. The fever clearance time ranged from 0 to 82 hours in the artemether group and from 0 to 93 hours in the quinine group. The mean fever clearance time was not significantly different between the two groups ( $35.5 \pm 23.3$ hours vs $37.4 \pm 24.7$ hours). The parasite clearance time ranged from 11.5 to 77 hours in the artemether group and from 17 to 88 hours in the quinine group. The mean parasite clearance time showed $50 \%, 90 \%$ and $100 \%$ reductions when compared between these groups, and were not significantly different $(16.9 \pm 10.3$ hours vs $21.3 \pm 12.6$ hours, $29.3 \pm 12.3$ hours vs $29.4 \pm 10.7$ hours and $38.9 \pm 16.9$ hours vs $41.8 \pm 14.7$ hours). The consciousness recovery time of the cerebral malaria patients ( 7 cases) ranged from 22 to 42 hours in the artemether group ( 5 cases) and from 37 to 90.5 hours in the quinine group
( 2 cases). The mean unconsciousness recovery time between these groups $(32 \pm 14.1$ hours vs $62.8 \pm 19.2$ hours) was not significantly different (Table 7).

\section{Comparative side effects between treatment groups}

There were mild and self-limiting symptoms (side effect) reported in both groups. In the artemether group, no pain and abscess at the injection site were noted. While in the quinine group, tinnitus (22\%), nausea (4\%), and hickups $(4 \%)$ were reported.

\section{DISCUSSION}

The mortality rate of severe malaria remains high despite prompt treatment with loading dose of quinine infusion. The unsatisfactory treatment outcomes with this regimen led to a multicenter study of artemether as an alternative antimalarial drug for the treatment of severe and complicated falciparum malaria, particul lary in multidrug resistant area such as East Kaliman$\tan$.

Table 7. Comparison of the efficacy of artemether and quinine in severe and complicated falciparum malaria patients at Balikpapan General Hospital, Balikpapan, East Kalimantan, 1993-1995.

\begin{tabular}{|c|c|c|c|}
\hline Therapeutic response & $\begin{array}{l}\text { Artemether } \\
\text { group }^{*}\end{array}$ & $\underset{\text { group }}{\text { Quinine }^{\dagger}}$ & $\begin{array}{l}\text { Chi-square or } \\
\text { Student's t-test }\end{array}$ \\
\hline Survival Rate $(\%)^{\ddagger}$ & $26 / 30(87)$ & $23 / 30(77)$ & NS \\
\hline Parasite Clearance Rate $(\%)^{\ddagger}$ & $26 / 26(100)$ & $23 / 23(100)$ & NS \\
\hline $\begin{array}{l}\text { Fever Clearance Time } \\
(\bar{x} \pm S D) \text { hour }\end{array}$ & $35.5 \pm 23.3$ & $37.4 \pm 24.7$ & NS \\
\hline $\begin{array}{l}\text { Parasite Clearance Time }(50 \%) \\
(\bar{x} \pm S D) \text { hour }\end{array}$ & $16.9 \pm 10.3$ & $21.3 \pm 12.6$ & NS \\
\hline $\begin{array}{l}\text { Parasite Clearance Time }(90 \%) \\
(\overline{\mathrm{x}} \pm \mathrm{SD}) \text { hour }\end{array}$ & $29.3 \pm 12.3$ & $29.4 \pm 10.7$ & NS \\
\hline $\begin{array}{l}\text { Parasite Clearance Time }(100 \%) \\
(\overline{\mathrm{x}} \pm \mathrm{SD}) \text { hour }\end{array}$ & $38.9 \pm 16.9$ & $41.8 \pm 14.7$ & NS \\
\hline $\begin{array}{l}\text { Recovery Time of Consciousnes } \\
(\bar{x} \pm S D) \text { hour }\end{array}$ & $32 \pm 14.1^{\S}$ & $62.8 \pm 19.2^{11}$ & NS \\
\hline $\begin{array}{l}\text { Case Fatality Rate of Cerebral } \\
\text { Malaria (\%) }\end{array}$ & $3 / 8(37.5)$ & $5 / 7(71.4)$ & NS \\
\hline
\end{tabular}

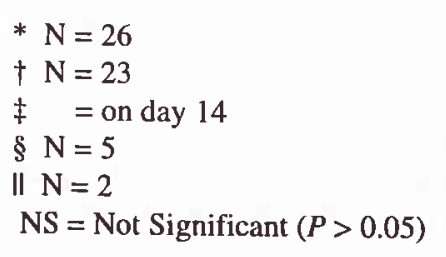


Artemether's activity against the early forms of the parasite may be useful in preventing the sequestration of the later stages associated with severe malaria. In the preliminary report for this study and in most of the clinical trials in severe falciparum malaria, artemether was good. This drug was superior to chloroquine, sulfadoxine-pyrimethamine and quinine, as evi denced by the faster fever and parasite clearance time and recovery time of consciousness, and the lower mortality rate. $7,12,18-21$ These reports suggest that artemether may stop tissue destruction and prevent death more efficiently than other antimalarials, although reduction in mortality related to intravenous quinine have not been demonstrated in randomized trial with a single exeption.

The present study did not confirm the superiority of artemether over quinine. The survival rate, parasite clearance rate, mean fever and parasite clearance time, recovery time of consciousness, and case fatality rate between the two groups were not significantly different. The number of cases in this study may be not sufficient to confirm the superior efficacy of artemether against severe and complicated falciparum malaria adult patients.

In Nigerian children with cerebral malaria, artemether also did not show superiority over quinine. ${ }^{22}$ In Gambia, artemether and chloroquine had equally rapid action in the treatment of severe malaria in children. ${ }^{19}$

Death in the artemether group mostly (75\%) occurred within the first 48 hours. While in the quinine group mostly (71\%) occurred after the first 48 hours. This finding may be related to the pathogenesis of severe malaria. In severe malaria, a number of sequestered trophozoites and schizonts in capillaries in various tissues are expected, and artemether may be able to rapidly clear the parasites only in the circulation. ${ }^{8,23}$

The fatal cases in this study were mainly those with more than 3 complications and those associated with complications such as hypercreatininaemia, bleeding, pulmonary edema, acidosis and septic shock. In the preliminary report and a previous study with intravenous quinine, the fatal cases were those with more than 2 complications and those associated also with pulmonary edema, septic shock, bleeding, hypercreatininaemia, tachypnoea, hyperbilirubinaemia, hypoglycaemia, leucocytosis and hypotension. 7,21

Most of the patients in this study were referred from outside Balikpapan and could be followed up for only 14 days. All of the surviving patients were cured.
Ideally, the follow up period should be 28 days to look for recrudescence, which generally occured within 4 weeks of treatment. ${ }^{24-25}$

In the present study, the mortality rate of severe and complicated falciparum malaria patients was quite similar with that described in the preliminary report $(18.3 \%$ vs $19.2 \%),{ }^{21}$ and lower than a previous study $(18.3 \%$ vs $39 \%) .^{7}$ In Thailand, the mortality rates of severe malaria were between 8 and $25 \%{ }^{26}$

The case fatality rate of cerebral malaria in this study was higher than in the preliminary report $(53.3 \%$ vs $42.9 \%),{ }^{21}$ and similar with a previous study $(53.3 \% \mathrm{vs}$ $50 \%){ }^{7}$ The use of the Glasgow Coma Scale in this present study $(\mathrm{GCS}<9)$ might have influenced the outcome of the treatment.

\section{CONCLUSION}

Intramuscular artemether was well tolerated and as effective as intravenous quinine treatment of severe and complicated faleiparum malaria. This drug is a good alternative to quinine, particularly in remote areas lacking hospitals and the capability for intravenous infusion.

\section{Acknowledgements}

The authors would like to thank the following for their invaluable assistance: the Head of Communicable Disease Research Center, National Institute of Health Research and Development, Ministry of Health, Jakarta, Republic of Indonesia; the Head and staff of Directorate of Vector Borne Disease, Directorate General of Communicable Diseases Control and Environmental Health, Jakarta, Indonesia; the Director and staff of Balikpapan General Hospital, Balikpapan, East Kalimantan, Indonesia; and Rhone Poulenc Rorer Doma, Jakarta, Indonesia.

\section{REFERENCES}

1. Tjitra E. Report of Clinical trial of halofantrine in the treatment of falciparum malaria patients in a chloroquine resistant area. Jakarta: Ministry of Health, National Institute of Health Research and Development, Communicable Disease Research Center; 1991 Apr.

2. Tjitra E, Marwoto HA, Renny M, Sulaksono S, Ompusunggu S. Antimalarial drug study. Bull Hlth Studies 1992;19(4): 15-23.

3. Hadisaputro S, Ardana K, Djamil A. Clinical pattem and severe malaria management in RA Kartini General Hospital, Jepara, Central Java. In: Pribadi W, Mulyono R, Sutanto I editors. Malaria. Proceedings of Malaria Symposium; 1991 
May 2: Jakarta. Jakarta: Faculty of Medicine of the University of Indonesia, 1991:71-84.

4. Hartono FX, Syamsuridjal, Regomal T. Malaria in Samarinda. In: Proceedings of the IVth KOPAPDI; 1978: Medan. Medan: PAPDI, 1978.

5. Elya K, Soeharyo, Ardana K. Cerebral malaria in RA Kartini Hospital (Jepara). In: Proceedings of the IVth KOPAPDI; 1984: Jakarta. Jakarta: PAPDI, 1984:2047-55.

6. Sarumpaet B, Hoffman SL, Punjabi NH, Dimpudus AJ, Sandjaja B, Laughlin LW, et al. Cerebral malaria in adult patients in RSUP Jayapura. In: Proceedings of the IVth KOPAPDI; 1984: Jakarta. Jakarta PAPDI, 1984:2174-87.

7. Tjitra E, Richie TL. Preliminary report of Immunology study on cerebral malaria patients in Manado and Tomohon Hospitals, 1993- 1994. Jakarta: Ministry of Health, National Institute of Health Research and Development, Communicable Disease Research Center, 1994 Apr.

8. Qinghaosu Antimalaria Coordinating Research Group. Antimalaria studies in Qinghaosu. China Med J 1979;92:81 1-6.

9. Bunnag D, Viravan C, Looareesuwan S, Karbwang J, Harinasuta T. Clinical trial of artesunate and artemether on multidrug resistance falciparum malaria in Thailand. A preliminary report. South east Asian J Trop Med Publ Hlth 1991;22:380-5.

10. Hien TT, Arnold K. Artemisinin and its derivates in the treatment of falciparum malaria in Vietnam. In: Tharavanij S, Fungladda W, Kusmith S, Pruekwatana O, editors. Abstracts volume 1. Proceedings of the XIIIth International Congress for Tropical Medicine and Malaria; 1992 Nov 29-Dec 4: Jomtien. Bangkok: Faculty of Tropical Medicine, Mahidol University, 1992:66-7.

11. Li GQ. Clinical trials on artemisinin and its derivates in treat ment of malaria in China. In: Tharavanij S, Fungladda W, Kusmith S, Pruekwatana O, editors. Abstracts volume 1. Proceedings of the XIIIth International Congress for Tropical Medicine and Malaria; 1992 Nov 29-Dec 4: Jomtien. Bangkok: Faculty of Tropical Medicine, Mahidol University, 1992:68-9.

12. Myint PT, Shwee T. A controlled clinical trial of artemether (qinghaosu derivate) versus quinine in complicated and severe falciparum malaria. Trans Roy Soc Trop Med Hyg 1987;81:559-61.

13. World Health Organization. Chemotherapy of malaria and resistance to antimalaria. Report of a WHO Scientific Group. WHO Tech Rep Ser 1973;529.

14. WHO. Severe and complicated malaria. Trans Roy Soc Trop Med Hyg 1990;84:Suppl 2:1-65.

15. WHO, Regional Office for South-East Asia. The clinical management of acute malaria. South-East Asia Ser no 9, 3rd ed. New Delhi: WHO Regional Publications, 1990.

16. Departemen Kesehatan. Penatalaksanaan malaria berat di Rumah Sakit dan Puskesmas. Jakarta: Sub Direktorat
Malaria, Direktorat Jenderal Pemberantasan Penyakit Menular \& Penyehatan Lingkungan, Departemen Kesehatan Republik Indonesia, 1990.

17. Gilles HM. Management of severe and complicated malaria. A practical handbook. Geneva: World Health Organization, 1991.

18. Walker O, Salako LA, Risquat A. Comparative trial of im artemether (ARTM) and sulfadoxine-pyrimethamine (S-P) in severe falciparum malaria in Nigerian children. In: Proceedings of the 5th International Congress of Infectious Diseases; 1992 June 7-11: Nairobi. Nairobi: International Society for Infectious Diseases, Kenya Medical Research Institute and the World Health Organization, 1992.

19. White NJ, Waller D, Crawley J, Nosten F, Chapman D, Brewster D, et al. Comparison of artemether and chloroquine for severe malaria in Gambian children. Lancet 1992; 339:317-21.

20. Taylor TE, Wills BA, Kazembe P, Chisale M, Wirima JJ, Ratsma EYEC, et al. Rapid coma resolution with artemether in Malawian children with cerebral malaria. Lancet 1993;341:661-2.

21. Tjitra E, Oemijati S, Sulaksono S, Pribadi W, Arbani P, Oey TS, et al. Clinical comparison of artemether and quinine treatment of severe and complicated falciparum malaria patients in Indonesia. A preliminary report. Med $\mathbf{J}$ Indones 1995;4(4):235-46

22. Salako LA, Walker O, Sowunmi A, Omokhodion SJ, Adio $\mathrm{R}$, Oduola AMJ. Artemether in moderately severe and cerebral malaria in Nigerian children. Trans Roy Soc Trop Med \& Hyg 1994;88(Suppl 1):13-5.

23. Jiang JB, Li GQ, Guo XB, Kong YC, Amold K. Antimalarial activity of mefloquine and qinghaosu. Lancet 1982;2:285-8.

24. Tjitra E, Oemijati S, Arbani PR, Pribadi W. Clinical trials of artesunate and artemether on falciparum malaria in chloroquine resistant areas (A preliminary report). $\mathrm{J}$ Indones Med Assoc 1995;45(4):223-30.

25. Tjitra E, Pribadi W, Raharjo K, W Budiono, Arbani PR, Naibaho $\mathrm{P}$, et al. Treatment of uncomplicated in vitro chloroquine resistant falciparum malaria in Irian Jaya. Med J Indones 1996;5(1):33-41.

26. Tjitra E. Retrospective study of severe falciparum malaria manifestation in adult patients. Cermin Dunia Kedokteran 1989;54:26- 8 .

27. Shwee T, Myint PT, Htut Y, Myint W, Soe L. The effect of mefloquine-artemether compared with quinine on patients with complicated falciparum malaria. Trans Roy Soc Trop Med Hyg 1988;82:665- 6.

28. Karbwang J, Na-Bangchang K, Thanavibul A, Bunnag D, Chongsupha jaisiddhi T, Harinasuta T. Comparison of oral artemether and mefloquine in acute uncomplicated falciparum malaria. Lancet 1992;340:1245-8. 